\title{
Economic Impacts of Drought on the Florida Environmental Horticulture Industry
}

by Alan W. Hodges, PhD, and John J. Haydu, PhD

University of Florida, Institute of Food \& Agricultural Sciences

Food \& Resource Economics Department, Gainesville

Revised May 19, 2003

\begin{abstract}
An economic impact study of Florida's environmental horticulture industry in year 2000 was conducted with a telephone survey of over 2,200 businesses and households, and the use of regional economic models to determine the multiplier effect of income derived from outside the region. The study also assessed the impact of the ongoing drought in Florida and water use restrictions on the industry. Wholesale plant producers, landscape services, horticultural retailers and floral importers had total sales estimated at $\$ 9.91$ billion $(\mathrm{Bn})$ and total output of $\$ 6.89 \mathrm{Bn}$. Direct employment in the industry was 158,000 persons, with an additional 5,000 jobs created in other related industries. Total value added generated was $\$ 6.40 \mathrm{Bn}$, including $\$ 4.12 \mathrm{Bn}$ in labor income, and $\$ 462$ million in taxes paid to local, state, and federal governments. Purchases of horticultural goods and services by Florida households and institutions such as hotels, restaurants, and other commercial buildings, were estimated at $\$ 3.31 \mathrm{Bn}$. Plant producers, including nurseries, sod farms, and cut flower/foliage growers employed 38 thousand persons, managed production area of 173,000 acres, and sold plants valued at $\$ 2.25 \mathrm{Bn}$, of which 41 percent was shipped to markets outside the state. Landscape businesses employed 61,000 persons, and provided services such as landscape design, construction, and maintenance and related goods valued at $\$ 3.11 \mathrm{Bn}$. Horticultural retailers employed 53,000 persons, managed 82 million square feet of retail sales space, and had total sales of plants and related horticultural goods valued at \$3.64Bn. Floral importers in Miami-Dade County had sales of \$904 million and employed 6,100 persons. In addition, allied suppliers of inputs to the horticulture sector had sales of $\$ 363$ million and employed nearly 5,000 persons. Personal consumption expenditures by employees in the horticulture industry and allied businesses generated $\$ 1.91 \mathrm{Bn}$ in sales, $\$ 1.23 \mathrm{Bn}$ in value added income, and provided nearly 25,000 jobs. The study found that nurseries and landscape firms experienced a net decrease in sales of $\$ 245$ million due to drought in 2000 , while retailers reported increased sales, particularly for large volume outlets.
\end{abstract}

\section{The Environmental Horticulture Industry}

Nursery and greenhouse crops represent the sixth largest agricultural commodity group in the United States, with a farm gate value of $\$ 12.12$ billion $(\mathrm{Bn})$ in 1998, and are the fastest growing major segment of U.S. agriculture. Between 1991 and 1998, sales of US nursery and greenhouse crops increased by 16 percent in inflation-adjusted terms, representing an average annual growth of 2.0 percent. This growth was due to the continued strong demand for plants, driven by a robust economy, expansion in housing, and increasing per capita consumption. Retail expenditures for plant products in the US reached $\$ 54.79 \mathrm{Bn}$ in 1998, or $\$ 203$ per capita. In inflation-adjusted terms, per-capita expenditures increased by 27 percent between 1986 and 1998, or 2.1 percent annually. Nursery and greenhouse products are classified as floriculture crops and nursery crops. Floriculture crops, including annual and perennial flowering plants, cut flowers and cut cultivated greens, and foliage plants, represented $\$ 3.93 \mathrm{Bn}$ in sales in 1998, while nursery crops such as woody ornamental trees and shrubs, sod, and unfinished plant products represented $\$ 8.18 \mathrm{Bn}$ in sales or roughly two-thirds of industry value.

Florida is one of the leading states in the US nursery and greenhouse industry, ranked second to California, with a wholesale value of $\$ 1.28 \mathrm{Bn}$ in 1998. Ornamental plants are one of the largest agricultural commodity groups in Florida, together with citrus and winter vegetables. Florida dominates the US market for tropical foliage crops, with over 85 percent of sales. Overall sales for greenhouse and nursery crops by Florida growers increased by 24 percent during the period 199198 , or 10.7 percent in inflation-adjusted terms, representing annual growth of 1.3 percent. 


\section{Study Methods}

This study was undertaken to update a previous economic impact study of the Florida environmental horticulture industry for 1997. Estimation of the economic value of Florida's horticultural industries was based primarily upon information obtained from surveys conducted with five different groups: wholesale nurseries, horticultural retailers, landscape service providers, residential households, and institutional/commercial consumers. The wholesale nurseries, retailers, and landscape service providers represent the primary business sectors of interest, while the consumer sectors were surveyed to provide an independent estimate of consumer demand for horticultural products and services. The information was collected through telephone interviews, and by fax to provide adequate sampling in some counties. Telephone surveys of horticulture industry firms and consumers were performed under subcontract by the University of Florida's Bureau of Economic and Business Research, during the period July to October, 2001. A total of nearly 2,200 completed surveys were done, including 668 nurseries, 409 landscape service firms, 333 horticultural retailers, 452 institutions, and 321 households. The survey was designed as a simple random sampling plan within 10 selected Florida counties: Miami-Dade, Broward, Palm Beach, Orange, Lake, Volusia, Hillsborough, Manatee, Lee, and Gadsden.

Listings of firms for the survey were obtained from a variety of sources. A list of certified nurseries and stock dealers (horticultural retailers) was obtained from the Florida Department of Agriculture, Division of Plant Industry. A listing of Florida landscape services firms and commercial or institutional consumers in selected businesses were taken from the Reference USA database, based on standard industrial codes (SIC). The commercial-institutional consumer group represented firms drawn from different including primary schools, colleges/universities, restaurants, hotels, museums/galleries/gardens, religious organizations, governments, and commercial building maintenance services. The University of Florida Bureau of Economic and Business Research provided randomly selected residential households.

Firms interviewed for the survey were as having sold horticultural products or services last year, while households and commercial/institutional consumers were qualified as having a maintained landscape at their location last year. A total of nearly 18,000 telephone calls were made for the survey, of which 12 percent were completed, 0.3 percent were incomplete interviews, 4 percent were refused, 21 percent had technical difficulties, 50 percent had no answer or were not available. A total of 66 percent of firms or households that called were ineligible for the survey under the screening criteria indicated above.

Survey data was collected for fiscal year 2000. Information collected from the primary business sectors included annual sales, employment, area managed (nurseries, retailers), types of horticultural goods or services sold, types of plant products sold, sales to different customer markets, regional sales, marketing practices, changes in business volume and pricing, the outlook for business, and financial borrowing practices and considerations (nurseries). Information collected from the consumer sectors included landscape area maintained, value of purchases of plants, other horticultural goods and horticultural services, types of plant products purchased, types of vendors purchased from, and factors considered for purchasing plants and selecting vendors. Information was also collected for the first time on the effect of drought or water use restrictions on horticultural sales or purchases.

The value of imported fresh cut flowers shipped through the port of Miami were also included in this economic impact study for the first time. Information on value of sales, employment, and warehouse space used by importers were obtained from the Association of Floral Importers of Florida (Miami), whose members represent approximately 85 percent of the floral import industry in Florida. Output of the retail and trade sectors was taken as the gross margin on sales. For floral importers, a gross margin of $48.5 \%$ was calculated based on the cost of imported product. For the retail sector, gross margin was taken from averages for the retail sector in Florida reported for the retail industry. County level information on employment and payroll expense was compiled for nurseries (SIC 018), retail garden centers (SIC 526), and landscape service firms (SIC 078), from the Florida Department of Labor, to estimate economic impacts for the major counties in Florida from controlled totals for the 
state of Florida.

For each survey variable and derived variable, descriptive statistics were computed, including the mean (average), standard error, number of respondents, and sum of sample values. The 95 percent confidence interval for the mean was taken as the estimated mean plus or minus 1.96 times the standard error. The value of sales or purchases by each firm or household were estimated as the lognormal mean for each to account for the highly skewed distribution of firm sizes. Sales of specific products or services by industry firms, and sales by market segment or region, were estimated as a percentage of total sales for each industry sector, with the total controlled to the amount estimated from the expansion formula. Similarly, purchases of specific products or services by consumers, and purchases by type of vendor, were estimated as a percentage of total purchases, with the total amount controlled. Estimates of the total value of sales or purchases for the entire population of firms or households were based on expansion factors that represent the ratio of the population to the number sampled, as shown in Table 1 . Expansion factors were calculated as $F=P / S$ * $(1-E)$, where $F$ is the expansion factor, $P$ is the Florida population, $S$ is the number of firms/households that reported sales or total value of purchases, and $E$ is the percentage of firms/households ineligible for the survey. The population of firms was adjusted down to account for the percentage of firms that were ineligible for the survey according to the screening questions discussed above.

\begin{tabular}{|c|c|c|c|c|c|}
\hline Survey Group & $\begin{array}{l}\text { Sample } \\
\text { Number }\end{array}$ & Population & $\begin{array}{l}\text { Ineligible } \\
\text { Contacts } \\
\text { (percent) }\end{array}$ & $\begin{array}{c}\text { Respondents } \\
\text { Reporting } \\
\text { Sales or } \\
\text { Purchases }\end{array}$ & $\begin{array}{c}\text { Expansion } \\
\text { Factor for } \\
\text { Sales or } \\
\text { Purchases }\end{array}$ \\
\hline Nurseries & 668 & 3,888 & $51.6 \%$ & 621 & 3.0 \\
\hline Retailers & 333 & 8,113 & $52.0 \%$ & 273 & 14.3 \\
\hline Landscapers & 400 & 8,467 & $67.8 \%$ & 373 & 7.3 \\
\hline Institutions & 452 & 19,887 & $55.3 \%$ & 416 & 21.4 \\
\hline Households & 321 & $5,881,000$ & $52.0 \%$ & 309 & 9136 \\
\hline Total & 2,174 & & & 1,992 & \\
\hline
\end{tabular}

Regional impacts and economic multipliers were developed with an input-out model and social accounting matrix, IMPLAN Pro software licensed from MIG, Inc, and the associated databases for Florida, 1999. The IMPLAN databases consist of a set of social/economic accounts which describe the structure of the US economy in terms of transactions between households, governments, and 528 standardized industry sectors classified on the basis of the primary commodity or service produced (SIC's). The databases also describe local or regional economies, at the county level, in terms of industry output, value added, employment, imports and exports. IMPLAN uses a matrix inversion procedure to develop economic multipliers which reflect the direct, indirect and induced impacts of specified changes in final demand, output or employment for any given industrial sector. Indirect impacts result from changes in economic activity of other industrial sectors which supply goods or services to the sector being evaluated. Induced impacts are the result of personal consumption expenditures by industry employees. The total economic impact is the sum of direct, indirect and induced impacts. Multipliers were compiled from IMPLAN for economic output, employment, value added, labor income, and indirect business taxes. The latter two measures are components of value added. Economic multipliers represent the strength of backward linkages in the regional economy to other sectors that supply inputs to an industry. 
Regional models of the Florida economy were constructed with IMPLAN for the state as a whole, and for six regions (Fig. 1). Multipliers for the nursery, retail, landscape services, and wholesale trade sectors are given in Table 2. Economic impacts of each sector and subregion of the horticultural industry were calculated for each type of impact using the direct multiplier multiplied against local or state sales, and the total effects multiplier multiplied against sales outside the region. Non-local sales were treated differently than local sales because they bring "new" money into the local economy and expand its economic activity through the multiplier effect. Total employment impacts were estimated from survey data for the direct effects, and from multipliers for the indirect and induced effects. Results for each region were computed independently, based on sales, employment,

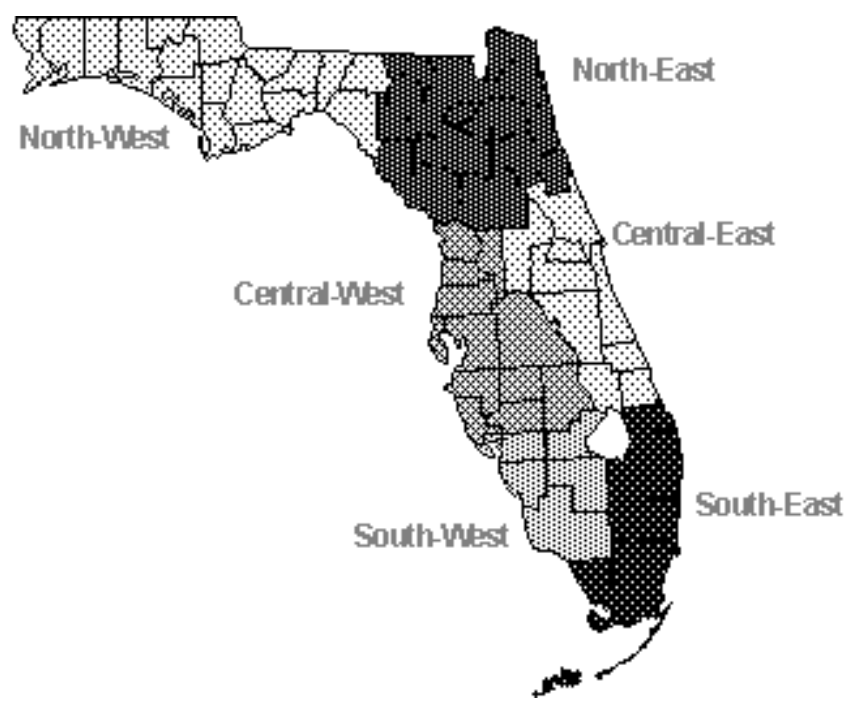

Figure 1. Florida regions for the horticulture industry. trade balances, and region-specific multipliers, so the sum of estimated regional impacts may not necessarily equal the total statewide estimates. Economic impact estimates for 1997 were re-stated from the previous study using updated economic multiplier. Also the definition of economic output was changed to represent only the gross margin for the retail sector, and information was added for the sod, cut flower/foliage and import sectors.

Table 2. Implan output and employment multipliers for Florida horticulture industry sectors (1999)

\begin{tabular}{lcccc}
\multicolumn{1}{c}{ Type/Sector } & $\begin{array}{c}\text { Direct } \\
\text { Effects }\end{array}$ & $\begin{array}{c}\text { Indirect } \\
\text { Effects }\end{array}$ & $\begin{array}{c}\text { Induced } \\
\text { Effects }\end{array}$ & $\begin{array}{c}\text { Total } \\
\text { Effects }\end{array}$ \\
\hline Output & & & & \\
Nursery & 1.000 & 0.193 & 1.124 & 2.317 \\
Landscape Services & 1.000 & 0.329 & 1.076 & 2.405 \\
Retail & 1.000 & 0.123 & 1.274 & 2.396 \\
Trade (floral imports) & 1.000 & 0.251 & 1.166 & 2.417 \\
Employment (jobs/\$million output) & & & & \\
Nursery & 13.7 & 3.0 & 14.5 & 31.2 \\
Landscape Services & 33.9 & 4.0 & 14.0 & 51.9 \\
Retail & 20.3 & 1.4 & 17.0 & 38.7 \\
Trade (floral imports) & 9.0 & 3.0 & 15.6 & 27.6 \\
\hline Source: Minnesa
\end{tabular}

Source: Minnesota Implan Group (MIG), Inc., Stillwater, MN. 2002.

\section{Results}

\section{Sales of Horticultural Products and Services}

The percentage of nursery, retail and landscape firm respondents by annual sales class is given in Table 3 . For all groups, about half of the respondents were in the small category of less than $\$ 250,000$ in annual sales. The percentage of respondents with reported annual sales of $\$ 250,000$ to $\$ 999,000$ was 29 percent for nurseries, 16 percent for retailers, and 28 percent for landscape firms. The percentage of firms with sales exceeding \$1 million was 17 percent for nurseries, 12 percent for retailers, and 17 percent for landscapers. Annual sales information was not available or the respondent did not know this for about 7 percent of nurseries, 18 percent of retailers, and 8 percent 
of landscape firms surveyed.

Table 3. Distribution of annual sales by surveyed firms, 2000

\begin{tabular}{lccc}
\multicolumn{1}{c}{ Annual Sales Category } & Nursery & Retail & Landscape \\
\hline less than $\$ 250,000$ & $45 \%$ & $55 \%$ & $45 \%$ \\
$\$ 250,000$ to $\$ 499,000$ & $17 \%$ & $9 \%$ & $17 \%$ \\
$\$ 500,000$ to $\$ 999,000$ & $12 \%$ & $7 \%$ & $11 \%$ \\
$\$ 1,000,000$ to $\$ 1,999,999$ & $11 \%$ & $4 \%$ & $7 \%$ \\
$\$ 2,000,000$ to $\$ 3,999,999$ & $3 \%$ & $4 \%$ & $5 \%$ \\
$\$ 4,000,000$ to $\$ 5,999,999$ & $2 \%$ & $0 \%$ & $1 \%$ \\
$\$ 6,000,000$ to $\$ 7,999,999$ & $0 \%$ & $1 \%$ & $1 \%$ \\
$\$ 8,000,000$ to $\$ 9,999,999$ & $0 \%$ & $1 \%$ & $0 \%$ \\
$\$ 10,000,000$ or more & $1 \%$ & $2 \%$ & $3 \%$ \\
Don't know & $1 \%$ & $11 \%$ & $2 \%$ \\
Not available & $6 \%$ & $7 \%$ & $6 \%$ \\
Total & $100 \%$ & $100 \%$ & $100 \%$ \\
\hline
\end{tabular}

Sales of horticultural products and services in years 2000 is summarized in Table 4. Total sales by Florida producers, service providers, retail and trade businesses in 2000 were $\$ 9.867$ billion $(\mathrm{Bn})$. Sales for the producer sector amounted to $\$ 2.251 \mathrm{Bn}$, including nurseries $(\$ 1.75 \mathrm{Bn})$, sod farms (\$307 million), and cut flowers and cultivated greens (\$199 million). Sales for landscape firms were estimated at $\$ 3.11 \mathrm{Bn}$. Sales for retailers were $\$ 3.64 \mathrm{Bn}$. Sales were $\$ 904$ million for floral importers. Total industry sales increased from $\$ 7.092 \mathrm{Bn}$ in 1997, representing growth of approximately 39 percent, or 13 percent annually. Sales were increased significantly in all sectors. The very large increase in sales for the retail sector $(36 \%)$ may represent an underestimate for this group surveyed in 1997.

Table 4. Sales by Florida horticulture industry, 2000 and growth since 1997

\begin{tabular}{lcc} 
Sector & $\begin{array}{c}\text { Sales 2000 } \\
(\$ \text { million) }\end{array}$ & $\begin{array}{c}\text { Percent } \\
\text { Annual } \\
\text { Growth 97-00 }\end{array}$ \\
\hline Production & 2,251 & $7.5 \%$ \\
$\quad$ Nursery & 1,745 & $6.4 \%$ \\
Sod & 307 & $11.3 \% *$ \\
Cut Flowers \& Greens & 199 & $4.4 \%$ \\
Landscape & 3,110 & $5.0 \%$ \\
Retail & 3,643 & $36.0 \%$ \\
Trade (floral imports) & 904 & $4.3 \%$ \\
Total & 9,867 & $13.0 \%$ \\
\hline${ }^{*}$ Annual growth rate reflects 4 years. \\
\hline
\end{tabular}

For purposes of economic impact analysis, sales of horticultural products and services were compiled by market region. Sales were classified as international, national, state or local, with the local area defined as the city or county in which the business was located, or within a 50 mile radius. For nurseries, $\$ 995$ million or 56 percent of total sales were to state or local markets, while $\$ 749 \mathrm{M}$ $(43 \%)$ of sales were to national and international markets. For retailers and landscapers, 87 percent and 92 percent of sales, respectively, were to local or state markets. Total output was $\$ 6.892 \mathrm{Bn}$, with in-region output of $\$ 5.210 \mathrm{Bn}(76 \%)$ and ex-region output of $\$ 1.673 \mathrm{Bn}(24 \%)$. 


\section{Horticulture Industry Customers}

Sales of horticultural products and services to different types of customers are summarized in Table 5. For nurseries, the most important customers were re-wholesalers or brokers $(20 \%)$, landscape service firms (16\%), other growers (16\%), independent retail garden centers (14\%), developers $(12 \%)$, and mass merchant retailers $(12 \%)$, with direct sales to the public and other customers representing 6 percent. For retailers and landscape firms, by the most important customer segment was homeowners, representing 48 percent and 30 percent of total sales, respectively. Other important customers for retailers and landscape firms were commercial establishments (14\%, 17\%), apartments and condominiums (11\%, 19\%), and landscape firms (11\%). In addition, builders and developers were large customers for landscape services (21\%).

Table 5. Sales by type of customer for Florida horticulture industry, 2000

\begin{tabular}{|c|c|c|c|}
\hline Type of Customer/Sector & $\begin{array}{l}\text { Percent } \\
\text { Firms }\end{array}$ & $\begin{array}{l}\text { Percent } \\
\text { Sales }\end{array}$ & $\begin{array}{l}\text { Total Sales } \\
\text { (\$million) }\end{array}$ \\
\hline \multicolumn{4}{|l|}{ Nursery } \\
\hline Re-wholesalers or brokers & $66 \%$ & $20.4 \%$ & 356 \\
\hline Landscapers, interiorscapers or lawn maintenance firms & $65 \%$ & $19.8 \%$ & 345 \\
\hline Growers & $61 \%$ & $16.4 \%$ & 286 \\
\hline Garden centers and other retailers & $42 \%$ & $14.1 \%$ & 247 \\
\hline Developers or property managers & $33 \%$ & $11.9 \%$ & 207 \\
\hline Retail mass merchandisers & $23 \%$ & $11.5 \%$ & 201 \\
\hline Directly to the public (homeowners) & $33 \%$ & $5.1 \%$ & 88 \\
\hline Other types customers & $5 \%$ & $0.9 \%$ & 15 \\
\hline Total & & $100.0 \%$ & 1,745 \\
\hline \multicolumn{4}{|l|}{ Retail } \\
\hline Homeowners & $65 \%$ & $48.2 \%$ & 1,755 \\
\hline $\begin{array}{l}\text { Commercial establishments (e.g restaurants, hotels, and } \\
\text { offices) }\end{array}$ & $49 \%$ & $13.9 \%$ & 506 \\
\hline Apartments and condominiums & $46 \%$ & $11.4 \%$ & 416 \\
\hline Landscapers, interiorscapers or lawn maintenance firms & $18 \%$ & $11.4 \%$ & 415 \\
\hline Other retailers & $13 \%$ & $8.8 \%$ & 322 \\
\hline Government organizations & $18 \%$ & $6.3 \%$ & 230 \\
\hline Total & & $100.0 \%$ & 3,643 \\
\hline \multicolumn{4}{|l|}{ Landscape } \\
\hline Homeowners & $75 \%$ & $30.1 \%$ & 936 \\
\hline Builders or Developers & $31 \%$ & $20.7 \%$ & 643 \\
\hline Apartments and condominiums & $45 \%$ & $19.4 \%$ & 604 \\
\hline Commercial establishments & $58 \%$ & $16.6 \%$ & 515 \\
\hline Government organizations & $21 \%$ & $9.9 \%$ & 307 \\
\hline Landscapers, interiorscapers or lawn maintenance firms & $16 \%$ & $3.4 \%$ & 104 \\
\hline Total & & $100.0 \%$ & 3,110 \\
\hline
\end{tabular}

\section{Area Managed}

Area managed by horticultural producers, retailers, and commercial/institutional consumers is summarized in Table 6 . Total production area was estimated at 173,000 acres, including 70,304 acres for nurseries, 80,347 acres for sod farms, and 22,010 acres for cut flowers/greens. Among nurseries, there was 22,853 acres in field production, 28,501 acres in open container production, and 18,950 acres ( 825 million square feet) covered area in greenhouse or shadehouse. Retail sales area totaled 1,878 acres (82 million square feet), with 63 percent of this space used for live plants. Landscape area maintained by selected types of institutions surveyed amounted to 238,612 acres. Landscape area maintained by households was estimated at 419,000 acres. 
Table 6. Area managed by the Florida horticulture industry, 2000

\begin{tabular}{lc} 
Type of Area & $\begin{array}{c}\text { Estimated Total } \\
\text { Area (Acres) }\end{array}$ \\
\hline Production area & $\mathbf{1 7 2 , 6 6 1}$ \\
Nurseries & 70,304 \\
Field nursery & 22,853 \\
Open container nursery & 28,501 \\
Greenhouse/shadehouse & 18,950 \\
Sod farms & 80,347 \\
Cut flowers \& cultivated greens & 22,010 \\
Retail sales area & 1,878 \\
Live Plants & 1,180 \\
Lawn and garden supplies & 196 \\
Lawn and garden hard goods & 115 \\
Other goods & 387 \\
Landscape area maintained & $\mathbf{6 5 7 , 7 0 8}$ \\
Institutions & 238,612 \\
Households & 419,096 \\
\hline
\end{tabular}

\section{Total Economic Impacts}

Total economic impacts of the horticulture industry were estimated using the IMPLAN inputoutput regional modelling system. The total output impact in year 2000 was estimated at $\$ 9.16$ billion $(\mathrm{Bn})$, including $\$ 6.89 \mathrm{Bn}$ in direct output impact from industry sales, plus $\$ 363 \mathrm{M}$ in indirect impacts from allied firms that supply inputs to the horticulture industry, and $\$ 1.91 \mathrm{Bn}$ in induced impacts associated with consumer spending by industry employees (Table 7). Note that the output of the retail and import trade sectors represents only the gross margin on sales, and the indirect and induced impacts applies only to the portion of output sold outside the state of Florida. The estimated total output impact increased by $\$ 2.23 \mathrm{Bn}$ between 1997 and 2000, representing a 32 percent increase, or 10.7 percent annually.

Value added is an important measure of an industry's contribution to a regional economy. It represents the difference between sales revenues and the cost of purchased inputs, and includes the value of employee wages and benefits, owner's compensation, dividends, capital outlays and business taxes paid. The total value added impact by Florida's horticulture industry was $\$ 6.40 \mathrm{Bn}$, including $\$ 4.12 \mathrm{Bn}$ in labor income. Value added by the horticultural production, service, retail, and trade sectors were $\$ 2.52 \mathrm{Bn}, \$ 2.13 \mathrm{Bn}, \$ 1.08 \mathrm{Bn}$, and $\$ 673$ million, respectively. Total value added by allied industries (indirect effects) amounted to $\$ 230$ million, and value added by employee spending was $\$ 1.23 \mathrm{Bn}$. Indirect business taxes paid to governments by the horticulture industry and allied firms were estimated at $\$ 462$ million.

Total employment associated with the horticulture industry was over 192,000 jobs, including 158,000 jobs directly in the commercial horticulture sectors, plus an additional 5,000 jobs in the allied supply businesses, and 25,000 jobs as a result of employee personal consumption expenditures. Total employment associated with the horticultural production, service, retail, and trade sectors were $54,000,64,000,56,000$, and 13,000 jobs, respectively. Total industry employment increased from 1997 by 13 percent, or 4.4 percent annually. 
Table 7. Total economic impacts of the Florida horticulture industry, 2000 and change from 1997

\begin{tabular}{|c|c|c|}
\hline Type/Sector & $\begin{array}{c}\text { Total } \\
\text { Impact } \\
2000\end{array}$ & $\begin{array}{l}\text { Percent Annual } \\
\text { Change Total } \\
\text { Impact } 97-00\end{array}$ \\
\hline \multicolumn{3}{|l|}{ Output (\$million) } \\
\hline Production* & 3,476 & $10.1 \%$ \\
\hline Landscape Services & 3,395 & $6.5 \%$ \\
\hline Retail & 1,296 & $45.3 \%$ \\
\hline Trade (floral imports) & 997 & $4.6 \%$ \\
\hline Total & 9,164 & $10.7 \%$ \\
\hline \multicolumn{3}{|l|}{ Value Added (\$million) } \\
\hline Production* & 2,518 & $10.8 \%$ \\
\hline Landscape Services & 2,130 & $0.1 \%$ \\
\hline Retail & 1,080 & $45.8 \%$ \\
\hline Trade (floral imports) & 673 & $4.5 \%$ \\
\hline Total & 6,401 & $8.7 \%$ \\
\hline \multicolumn{3}{|l|}{ Labor Income (\$million) } \\
\hline Production* & 1,608 & $18.9 \%$ \\
\hline Landscape Services & 1,418 & $-4.5 \%$ \\
\hline Retail & 669 & $42.4 \%$ \\
\hline Trade (floral imports) & 424 & $4.1 \%$ \\
\hline Total & 4,118 & $7.8 \%$ \\
\hline \multicolumn{3}{|c|}{ Indirect Business Taxes (\$million) } \\
\hline Production* & 90 & $18.8 \%$ \\
\hline Landscape Services & 94 & $7.7 \%$ \\
\hline Retail & 187 & $38.9 \%$ \\
\hline Trade (floral imports) & 91 & $3.5 \%$ \\
\hline Total & 462 & $17.6 \%$ \\
\hline \multicolumn{3}{|l|}{ Employment (jobs) $)^{\star *}$} \\
\hline Production (nursery, sod) & 54,288 & $5.9 \%$ \\
\hline Landscape Services & 64,282 & $0.9 \%$ \\
\hline Retail & 55,874 & na \\
\hline Trade (floral imports) & 13,416 & na \\
\hline Total & 187,859 & $4.4 \%$ \\
\hline $\begin{array}{l}{ }^{*} \text { Production sector includ } \\
\text { **Employment estimates }\end{array}$ & $\begin{array}{l}\text { y, sod, cut } \\
\text { survey res } \\
\text { of export s }\end{array}$ & $\begin{array}{l}\text { wers/foliage. } \\
\text { for direct }\end{array}$ \\
\hline
\end{tabular}

\section{Regional Economic Impacts}

Regional economic impacts of the Florida environmental horticulture industry are summarized in Table 8 for six regions. Direct employment, as reported to the Florida Department of Labor, was highest in the south-east Florida region $(33,543)$, closely followed by the central-west $(30,930)$, and central-east $(29,850)$ regions, then by the north-east $(17,743)$, south-west $(13,598)$ and north-west $(3,267)$. Total employment impacts were highest in the central-cast region $(45,320)$, followed by the southeast $(40,597)$ and central-west $(37,937)$. Total output impacts regionally were $\$ 2.27 \mathrm{Bn}$ in the central-east region, $\$ 1.96 \mathrm{Bn}$ in the south-east, $\$ 1.53 \mathrm{Bn}$ in the central-west, $\$ 1.10 \mathrm{Bn}$ in the northeast, \$550Mn in the south-west, and \$229Mn in the north-west. Note that these impacts do not reflect the sod farms and cut flower/foliage production sectors or the floral import sector. 
Table 8. Regional economic impacts of Florida nurseries, horticultural retailers and landscaped services sectors, 2000

\begin{tabular}{lccccc} 
Region or County & $\begin{array}{c}\text { Employme } \\
\text { nt Impacts } \\
\text { (jobs) }\end{array}$ & $\begin{array}{c}\text { Sales } \\
\text { (\$million) }\end{array}$ & $\begin{array}{c}\text { Output } \\
\text { Impacts } \\
\text { (\$million) }\end{array}$ & $\begin{array}{c}\text { Value } \\
\text { Added } \\
\text { Impacts } \\
\text { (\$million) }\end{array}$ & $\begin{array}{c}\text { Labor } \\
\text { Income } \\
\text { Impacts } \\
\text { (\$million) }\end{array}$ \\
\hline South-East Florida & 40,597 & 2,025 & 1,963 & 1,303 & 842 \\
Central-West Florida & 37,937 & 2,213 & 1,530 & 1,131 & 724 \\
Central-East Florida & 45,320 & 1,982 & 2,265 & 1,540 & 996 \\
North-East Florida & 27,900 & 903 & 1,101 & 742 & 487 \\
South-West Florida & 13,187 & 806 & 550 & 409 & 262 \\
North-West Florida & 3,585 & 168 & 229 & 188 & 120 \\
\hline
\end{tabular}

\section{Impacts of Drought on the Florida Horticulture Industry}

Drought and water use issues are of special concern in the horticulture industry.

During the past four years, many areas of Florida have experienced significantly below-normal rainfall. Anecdotal evidence indicated that many horticulture businesses have suffered severely in this situation due to limited availability of water for irrigation, water use restrictions, and loss of sales resulting from lower demand. However, drought could potentially benefit some horticultural business as a result of demand for replacement plants and water conserving equipment or supplies. As part of this study, we attempted to document the economic impact by asking survey respondents whether the drought during the last 4 years had affected their sales or purchases of plants. A majority of nurseries, landscape firms, and institutional consumers indicated that indeed their sales or purchases had been affected by the drought, while somewhat less than 50 percent of retailers and households expressed this opinion (Table 9). Among those respondents who indicated that they had been affected, over three-quarters said that their sales or purchases were decreased rather than increased. Moreover, for every group, the magnitude of change was greater in the negative direction than in the positive direction. The percentage change in sales or purchases was multiplied against the estimated total sales or purchases for each respondent, then expanded and summed together to reflect the net change in total industry sales or purchases. The net impact for all groups was negative, except for retailers. Nurseries and landscapers were estimated to have suffered a net decrease in sales of $\$ 61 \mathrm{Mn}$ and $\$ 184 \mathrm{Mn}$, respectively, while households and institutions reduced purchases by $\$ 109 \mathrm{Mn}$ and $\$ 3 \mathrm{Mn}$. The retail sector had a somewhat different outcome, with a net increase in sales of $\$ 80$ million, due mainly to sales growth reported by large volume retail chains.

Table 9. Impacts of drought on Florida sales and purchases of horticultural products and services, 2000

Response/Measure Nurseries Retailers Landscapers Institutions Households

Percent of respondents with sales or purchases of plants affected by drought during the last 4 years

"Yes" (affected by drought)

$56.1 \% \quad 41.1 \% \quad 56.0 \%$

$41.3 \% \quad 54.7 \% \quad 42.3 \%$

$58.4 \%$

$44.9 \%$

"No" (not affected by drought)

$39.6 \%$

$52.3 \%$

Percent respondents with sales or purchases increased or decreased

Increased

$7.0 \% \quad 15.3 \%$

$13.8 \%$

$88.2 \% \quad 79.6 \%$

$81.7 \%$

$15.5 \%$

$78.8 \%$

$17.4 \%$

Average percentage change in sales or purchases

\begin{tabular}{lccccc} 
Increased & $22.0 \%$ & $20.8 \%$ & $14.3 \%$ & $43.5 \%$ & $49.3 \%$ \\
Decreased & $24.3 \%$ & $23.5 \%$ & $33.1 \%$ & $53.8 \%$ & $63.0 \%$ \\
Estimated total change in sales or purchases & $\begin{array}{l}\text { (\$millions) } \\
\text { Increased }\end{array}$ & & & \\
Decreased & 35.4 & 234.0 & 15.36 & 1.4 & 96.0 \\
Net Difference & 96.8 & 154.4 & 199.1 & 4.1 & 204.7 \\
\hline
\end{tabular}


The net change in sales of horticultural products due to drought and their economic impacts on the horticulture industry were also estimated for the five Water Management Districts of Florida, which have varying water supply conditions and policies for water use restrictions (Table 10). The St. Johns, South Florida, and Southwest Florida Water Management Districts all had horticulture industry sales exceeding $\$ 2 \mathrm{Bn}$. The net change in horticulture industry sales was negative in all of the Water Management Districts. The largest change in sales due to drought occurred in the Southwest Florida Water Management Districts, with a loss of \$155 million, which represented approximately 7 percent of total industry sales. Horticulture businesses in the South Florida Water Management District and St. Johns River Water Management District also experienced significant losses in the nursery and landscape sectors, but these were partly offset by positive net changes for retailers.

Table 10. Net change in sales of horticultural products and services due to drought, and economic impacts in the Florida Water Management Districts, 2000

\begin{tabular}{|c|c|c|c|c|c|c|}
\hline \multirow{2}{*}{$\begin{array}{c}\text { Water Management } \\
\text { District }\end{array}$} & \multicolumn{4}{|c|}{ Net Change in Sales (\$million) } & \multirow{2}{*}{$\begin{array}{l}\text { Direct } \\
\text { Employment } \\
\text { Impacts } \\
\text { (jobs) }\end{array}$} & \multirow{2}{*}{$\begin{array}{c}\text { Direct Value } \\
\text { Added } \\
\text { Impacts } \\
\text { (\$million) }\end{array}$} \\
\hline & Nurseries & $\begin{array}{c}\text { Landscape } \\
\text { Services }\end{array}$ & Retailers & All Sectors & & \\
\hline Northwest & -1.3 & na & -2.1 & -3.4 & -34 & -1.7 \\
\hline Suwannee River & -2.3 & na & -0.6 & -2.9 & -42 & -2.3 \\
\hline St. Johns River & -8.1 & -47.2 & 14.4 & -40.9 & $-1,727$ & -33.1 \\
\hline Southwest & -18.6 & -69.0 & -67.4 & -155.0 & $-3,183$ & -77.6 \\
\hline South & -33.7 & -59.3 & 116.5 & 23.5 & $-1,957$ & -37.8 \\
\hline All & -64.0 & -175.5 & 60.8 & -178.6 & $-6,944$ & -152.4 \\
\hline
\end{tabular}

